\title{
Ethnomatematics Exploration in Traditional Games as A Form of Students' Social Interaction
}

\author{
Moh Zayyadi ${ }^{*}$, Sri Indriati Hasanah ${ }^{2}$, Ema Surahmi $^{3}$ \\ 1,2,3 Prodi Pendidikan Matematika, FKIP, Universitas Madura, Jl. Panglegur Km 3 No, 5, Panglegur, \\ Tlanakan, Kabupaten Pamekasan, Jawa Timur 69317, Indonesia \\ *Email : zayyadi@unira.ac.id , telp +6285330752474
}

Article received : 10 November 2017, article revised : 20 Februari 2018, article published: 21 Maret 2018

\begin{abstract}
The purpose of the study are To know the principles and concepts of ethnomatematics in traditional games in elementary level of mathematics learning and to know the utilization of traditional games in students' social interaction. Ethnomatematics is a mathematical practice in a cultural group. Mathematics as one of the subjects taught from elementary school to gain numeracy skills. In mathematics learning, informal knowledge of mathematics is developed into a mathematical concept through social interaction. Teachers and parents reintroduce traditional games to students in math learning activities in primary schools. this method aims to attract students to learn math by considering the material to be delivered and local culture. The form of social interaction of students in traditional games in learning mathematics is that students can become peer tutors of every game played along with mathematical concepts. The communication formed in the traditional game is one of the natural characteristics that occur, thus the traditional game can be used in the learning of mathematics as a form of social interaction between students based on the local culture.
\end{abstract}

Keywords : Ethnomatematics, Traditional Game; Social Interaction 


\section{INTRODUCTION}

Education and culture is inseparable in human life since culture is a comprehensive unity applied in a society. Education is a basic needs of human being, while in education and Mathematics learning, culture construct students' base concept. Things that can relate culture and education especially in Mathematics learning is Ethnomatematics. Ethnomathematics is a term that emerged in the 1980s, this occurs because of the interaction of mutual interaction between mathematical culture and political culture (Amit \& Qouder, 2017). According to (D 'ambrosio, 1985) argues ethnomatematics is: The prefix ethno is today accepted as a very Definisi broad term that refers to the socialcultural context and therefore includes language, jargon, and codes of behavior, myths, and symbols. The derivation of mathema is difficult, but tends to mean to explain, to know, to understand, and to do activities such as ciphering, measuring, classifying, inferring, and modeling. The suffix tics is derived from techne, and has the same root as technique (Rosa \& Orey 2011). In brief, Ethnomatematics is Mathematics fields influenced by culture, where one of this part is traditional games which is used to be played by children. (Brandt \& Chernoff, 2014) argue etnomathematics is a culturalbased mathematics, then integrated into mathematics classes.

(Kurniawati, Pranoto, \& Hong, 2014) argue traditional games as one of the local wisdom that bridges can use in educating young children early in life is at the stage of development which games play as a way to transfer the value of education in learning. Dharmamulya argues the elements of cultural values that children can learn in traditional games as follows: the value of pleasure or joy, friendship, democratic value, leadership, sense of responsibility, shared values and mutual help, the value of obedience, competent in calculating, practicing thinking skills, honesty value and sportsmanship (in Purwaningsih, 2006). Traditional games are rarely played in childhood now, technological and scientific developments have a major impact on traditional games, especially for children in big cities. Traditional games began to be abandoned by children and turned to modern games. The existence of gadgets, children become more interested in playing the game. The ease given by the technologies cause the children are currently less social, less creative and less concerned about their social environment. Before the presence of gadgets as a media game, children, especially primary school children first know the traditional game.

Traditional games teach children to be creative and socially interact. Social interaction in traditional games teaches the values of cooperation, sportsmanship, honesty and creativity. Various favorite traditional games in early times such as hide and seek, snake and ladder, cricket (bhisek), marbles, bentengan, bekel ball and so on. Play can also be used as a fun learning tool. Play and learning is a unity and a continuous process in the life of a child. Playing helps them to understand and practice their sense, intellectual, and social skills. Play should also be done with a sense of fun so that the playing activities result a learning process in children.

Mathematics is an abstract knowledge, so to understand it requires the ability to think (Zayyadi \& Subaidi, 2017). Mathematics is a tool for developing ways of thinking. Mathematics learning is not just for how students are good at arithmetic and solving math problems but it should also be able to teach their students to interact socially. Therefore math is necessary both for everyday life and in facing science and technology advancement so that math needs to be taught to students since elementary, even it can be started since kindergarten. Mathematics which is actually a science with normal and abstract deductive reasoning way, should be given to children since elementary school where their way of thinking is still at concrete operation stage (Prabowo \& Ristiani, 2011). These mathematical ideas arise 
naturally, through the knowledge and views of a particular ethnic or group of people or individuals without going through a formal education or training. Through this research, it is expected for further reinforce the idea of incorporating Ethnomatematics into the school curriculum (Zayyadi, 2017)

The purpose of mathematics in elementary schools is not only to understand the meaning, facts, and concepts contained in mathematics, but also to develop systematic, logical, critical attitudes and skills with careful attainment of knowledge. Education is closely related to every human development, started from physical development, health, skills, mind, feeling, willingness, social, and the development of faith. One way to improve the quality of education is improving the quality of learning, especially learning in elementary schools (SD), because the three basic skilled such as the ability to read, write, and count are taught in that level of education (Surahmi, 2016).

In learning Mathematics, students are not only taught to simply memorize mathematical formulas. Mathematical problems related to everyday life will make students understand the benefits of the science they learn. Actually, teachers sometimes do not notice that in traditional games, children can also learn mathematics, for example, children can learn to count through the game hide and seek.

The purpose of the study are: 1) To know the principles and concepts of ethnomatematics in traditional games in elementary level of mathematics learning. 2) To know the utilization of traditional games in students' social interaction.

\section{METHOD}

Type of this research is qualitative research with ethnography approach. Ethnography is used to describe, explain and analyze the cultural elements of a society or ethnicity. Before conducting the research, firstly, the researcher found and specified the informant. The informant in this study was a native speaker who speaks his own language or dialect as a source of information. In determining informants, some considerations were taken in order to meet an appropriate informants so that the informants were able to cooperate well. Fulfillment of criteria or requirements for informants in this study is much important since not everyone can be defined as informants. Instrument in this research is human instrument where the researchers act as main instruments and they cannot be replaced/represented to others. In this case, researchers directly deal with research and act as data collectors through library data collection, interviews, observation and documentation.

Data collection techniques in this study consists of two parts, namely: 1) Collection of literary data, by searching various literature related to Traditional games.

2) Data collection in the field, consisting of 3 parts which are interviews, observation and documentation. In conducting interviews and observations, researchers could simultaneously create documentation or take pictures that could be used as complementary data in research. Data and information obtained from literature, interviews, observations, and documentation are described as being for further analysis. Data analysis techniques performed with data substruction measures, data presentation, data analysis and research findings.

\section{RESULT AND DISCUSSION}

\section{Traditional Games}

The traditional game is a game played by the children in earlier times. Most of these games are done in a group, people in the past could practically not recognize the outside world which unwittingly directed and guided them to social activities and togetherness, which are the result of ideas of thought, creativity, proposed trial and error, included in the image of the minds of the our predecessors (Surahmi, 2016, 134).

The following traditional games are examples of games that use the concept of 
Ethnomatematics in learning mathematics, among others;

\section{Bhisek (Engklek)}

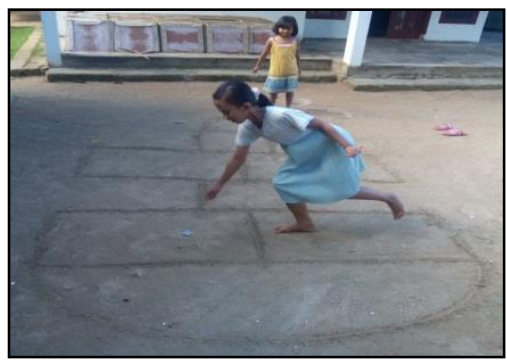

Picture 1. Games of Bhisek

\section{The Concept of Mathematics in the Game} of Bhisek

a. Addition and Subtraction

The sum operation is done when counting many players $1+1+1+1=4$ players.

b. Number

The concept of numbers is done by the children when they start playing (throwing rocks and jumping).

c. Lines and Angles

The concept of the line can be noticed at the time the children draw the plot (bhisek).

d. Two-dimentional figure

The concept of can be seen when children draw a plot of the same complex (bhisek) with a square / rectangle and the same mountain as the semicircle.

\section{e. Comparison}

The concept of comparison can be seen when children throw rocks / fractions tiles on the plot of englek (bhisek).

Social Interaction in the Game of Bhisek Cooperation, Sportive, togetherness and team cohesiveness.

\section{Rem-Ngerreman (Hide and Seek) The Mathematical Concept in the Rem- Ngerreman Game}

a. Addition and Subtraction

The Addition and subtraction operations are performed by the children during the hompimpah and suit to determine the order of players. The sum operation is performed to see how many players $1+1+1+1+1=5$ players.

b. Number

The concept of numbers is done by the children when they start playing. Starts from the numbers $1,2,3,4,5,6,7, \ldots$ so on, where it can be seen that the counted number is a positive integer which is a natural number.

Social Interactions in Rem-Ngerreman Games: Togetherness, competition

Bal-Bleken (Bola Bekel)

Mathematical Concepts on Bal-Bleken Games

a. Addition and Subtraction

The Addition and subtraction operation is performed by the children when performing the hompimpah and suit to determine the order of the player, further in playing and counting the keccek (designed small stone which will be picked while throwing the ball).

\section{b. Multiplication and Division}

Multiplication and division operation is done while counting how many keccek a player can be taken, for example how often they took 2 keccek. In the multiplication operation: $2+2+2=6(3 \times 2=6)$, it means there is 3 times of picking the keccek and while taking 2 pieces of keccek, $3+3=6$ ( 2 $\times 3=6$ ), it means there is 2 times they took 3 pieces of keccek.

\section{c. Comparison}

The concept of comparison can be seen when children throw the bekel ball and keccek to the floor.

\section{Social Interaction on Bal-Bleken Games:}

Togetherness, competition / competition (to be a winner), Sportive (accumulates the number of scores for the winner, determines the order of play). 


\section{Dakon (Congklak)}

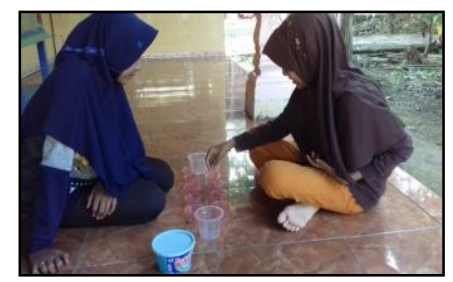

Picture 2. Dakon Games

Dakon or Congklak game is a game that is played by two people. The tool used is made of wood or plastic shaped like a boat with a length of about $75 \mathrm{~cm}$ and width of $15 \mathrm{~cm}$. At both ends there is a hole called a master plan hole. Among those holes there are smaller holes with diameter of approximately $5 \mathrm{~cm}$. Each series consists of 7 holes. In each small hole is filled with shells or grains as many as 7 pieces.

\section{Mathematical Concepts on Dakon Game}

\section{a. Addition and Subtraction}

The concept of Addition and subtraction at the time of filling the grains one by one into the hole that are passed including our own masterplan hole (the left) except the opponent's masterplan hole

b. Multiplication

c. Know Two-dimensional figure of circle / diameter of the dakon holes

\section{Social Interaction on Dakon Games}

Trained fine motor manipulation skills, concentration training, educating children's sportsmanship, training in strategy skills, counting learning tools.

\section{Gobak Sodor}

Gobak Sodor is played by dividing players into 2 groups, each consisting of 3-5 children. Then form boxes on a large square with 6 boxes ( 2 sideways and 3 rows). Each group is divided into attackers and guards. The responsibility of the guard group is to maintain a vertical line (each line of 1 child). And the responsibility of the attacking group is to attack or cross the vertical line in guard of the opposing group. The attack group must make it past the line and go to the back of the line (the final base), then return to the starting line.

\section{Mathematical Concepts on Gobak Sodor} Game:

a. Know Two-dimensional figure (quadrilateral)

The concept of Know Two-dimensional figure can be seen when children draw a plot of the same complex (bhisek) with a square / rectangle and the same mountain as the semicircle.

b. Fractional and fractional simplification The concept of a fraction in terms of giving the lines on one of the rectangles/rectangles so that students can understand the concept of fractions and simplify it.

\section{Social Interaction on Gobak Sodor Games} Accuracy, Sportive, and togetherness.

\section{Layang-layang (Lajengan)}

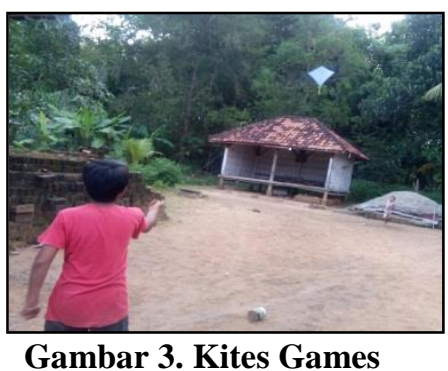

Kites is fun game, this game is mostly played by rural children, and usually kites in village are shaped like a rhombus. Kite play is seasonal, and every region has different times.

\section{Mathematical Concepts in Kites Games:}

a. Know Two-dimensional figure (kite and rhombus)

Know Two-dimensional figure in this case is kite and rhombus. Concept of this kite is at the time of making stems made of bamboo / wood.

b. Calculating the circumference and area of the Two-dimensional figure (kite and rhombus) The concept of circumference and Twodimensional figure in this game is when they make the bar of the kite so it can fly well. 
c. The concept of Two-dimensional figure, properties, widespread concept on the kite

\section{Social Interaction on the Kites Games:}

Accuracy, Sportive, and togetherness

\section{Pletokan (Ba'-Temba'an)}

Pletokan is played by making two groups and look for places for hide and shoot. Bullets are made of paper that is dampened, round and then is put into the bamboo hole. The player has three opportunity, if it has been hit by a shot for three times then it will fall. Round takes place twice, if it draw, games will be held the second round. At the beginning of the game there will be rules that will be carried out for the creation of security and sportsmanship.

\section{Mathematical Concepts on Ba'-Temba (Shooting Game)}

\section{a. Distance}

In this game the distance can be known at the time of shooting as far from the starting point and at the end point of the bullet.

\section{b. Time \\ c. Speed}

\section{Social Interaction on Ba'-Temba Game}

Togetherness, Accuracy, and Sportive Kelereng (Leker)

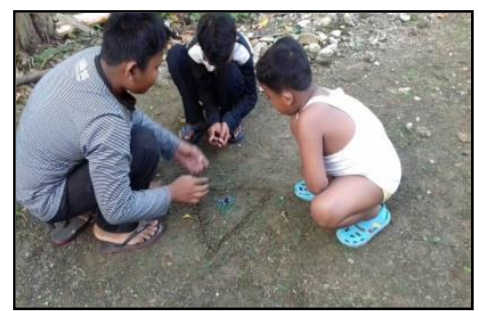

Picture 4. Marbles Games

This game is usually played on the ground. While playing, number of marbles will be placed in a circle that has been made before. Each player will attempt to remove the marble from within the circle. Who succeeds in removing the marbles from the circle, then he has the right to possess it. Marbles game uses a triangle: How to play the game is by drawing the isosceles triangle, then each player puts a marble above the image of the triangle. Make pairs of his name, marbles are at stake. Participants, depending on the number of players. Usually at least three players and at most ideally six players. If more than that made two groups.

The game begins with each player uses a marble as his gacoan or leading marble then throws them from a distance of two or three meters. Players alternately throw in sequence based on lucky draws with finger. Gacoan or leading marbles throw hard with the intention of it will land in the farthest game field. Players who successfully hit the pair of marbles, he got the first turn. If none make it, then who started playing is whose Gacoan or leading marbles get the farthest. Players should try to hit all the opposite marbles at the turn of play. Some players can hit all marbels in one opportunity. Sign him a skilled player. Various tactics to win are done, among others, if you do not want to hunt gacoan or leading marbles' opponent, then the choice is to fire gacoan to the empty place to be hidden so that it cannot be turned off by the opponents play. Players who are able to spend the last pair of fruit continued to hunt leading marble's opponent. The player who his leading marbles got shot then it die, and the game ended.

\section{Mathematical Concepts on Marbles Games:}

a. Concepts of scale and comparison

The scale and comparison in this game is who starts first in this game, which has the scale closest to the fulcrum and is paired with other players, then they started first.

b. The concept of measurement

\section{Social Interaction on marbles Games:}

Organize Emotions, Train Motor Abilities Train Thinking Ability, Competence Capability, Ability and Social and Honest.

\section{Social Interaction In Traditional Games And Mathematics Learning}


According to Vygotsky, every individual develops in a social context. All intellectual developments that include meanings, memories, thoughts, perceptions, and consciousness move from the interpersonal region to the intrapersonal region. The mechanism underlying high-level mental work is a copy of social interaction. In addition Vygotsky strongly emphasized the importance of the role of cultural environment and social interaction in the development of human traits and types (Slavin, Hopkins, Pearson, Paris, \& Ey, 2000)

According to Vygotsky (in Surahmi, 2016) students should learn through interaction with more capable adults and peers. This social interaction spurs the formation of new ideas and enriches the intellectual development of students. So, it can be either an adult or a peer. Active student learning emphasis needs to be developed. Students 'creativity and activeness will help them to stand alone in the students' cognitive life so that learning is directed towards experimental learning that is a humanitarian adaptation based on concrete experience. Briefly it can be said that a learning process will become more effective and efficient if the learners communicate with each other ideas through social interaction.

Social interaction within the scope of learning is created between educators and students, students and students. One way to prepare teachers to incorporate social interaction in their classes is to incorporate them into classroom learning. (Hurst, Wallace,
\& Nixon, 2013) . Interaction between students has a role that is not less important than the teacher, because students can learn a particular theme from their own experience, as an example when the traditional game in learning mathematics. Mathematics learning for elementary school which emphasizes on mathematics learning that appeals to students by not leaving the contents of the material. The social interaction that can be raised is how students can become tutors for their sabbatical friends on every traditional game played.

\section{CONCLUSION}

Conclusion in this study is 1) the concept of mathematics based on the surrounding culture (Ethnomathematics) on the traditional game in the mathematical learning that comes up is the concept, Distance, Time, Multiplication, Division, Addition, Subtraction Two-dimensional figure for the concept of circumference and area, comparison and Measurement. 2) The form of social interaction of students in traditional games in learning mathematics is that students can become peer tutors of every game played along with mathematical concepts. one of the forms of student's social interaction is Organize Emotions, Train Motor Abilities Train Thinking Ability, Competence Capability, Ability and Social and Honest.

\section{REFERENCES}

Amit, M., \& Qouder, F. A. (2017). Ethnomathematics and its Diverse Approaches for Mathematics Education, 23-51. https://doi.org/10.1007/978-3-31959220-6

Brandt, A., \& Chernoff, E. J. (2014). The Importance of Ethnomathematics in the Math Class. Ohio Journal of School Mathematics, (71), 31-38.

D 'ambrosio, U. (1985). Ethnomathematics and its Place in the History and Pedagogy of Mathematics. For the Learning of Mathematics .
Hurst, B., Wallace, R., \& Nixon, S. B. (2013). The Impact of Social Interaction on Student Learning, 52(4).

Kurniawati, Y., Pranoto, S., \& Hong, J. J. (2014). Indonesian Journal of Early Childhood Young Children Character Development through Javanese Traditional Game, 3(1), 54-58. https:// doi.org/10. 15294/ijeces.v3i1.9477

Prabowo, A., \& Ristiani, E. (2011). Rancang Bangun Instrumen Tes Kemampuan Keruangan Pengembangan Tes Kemampuan Keruangan Hubert Maier dan 
Identifikasi Penskoran 2 Berdasar Teori Van Hielle. JURNAL KREANO, 2(2), 7287.

Purwaningsih, E. (2006). Permainan Tradisional Anak: Salah Satu Khasanah Budaya yang Perlu Dilestarikan. Jantra, 1(1), 4046.

Slavin, R. E., Hopkins, J., Pearson, U., Paris, M., \& Ey, S. N. (2000). Educational Psychology: Theory and Practice. (Sixth Edition). Boston.

Surahmi, E. (2016). Permainan_Tradi-
sional_Dalam_Pembelajaran. In Permainan Tradisional Dalam Pembelajaran Matematika SD sebagai bentuk Interaksi Sosial Siswa.

Zayyadi, M. (2017). Eksplorasi Etnomatematika Pada Batik Madura. SIGMA, 2(2), 35-40.

Zayyadi, M., \& Subaidi, A. (2017). Berpikir Kritis Mahasiswa Dalam Memecahkan Masalah Aljabar, 8(2), 10-15. 